\title{
FACTORS AFFECTING CUSTOMER LOYALTY OF MOBILE RFID SERVICES IN KOREA
}

\author{
Yong-Jae PARK ${ }^{\text {a }}$, Myung-Hwan RIM' ${ }^{b}$, Seung-Koog LEE \\ ${ }^{a}$ Korea Institute of Ceramic Engineering and Technology, \\ 77 Digital-ro 10-gil, Geumcheon-gu Seoul, Republic of Korea \\ ${ }^{b, c}$ ETRI, Technology Strategy Research Division, 218 Gajeong-ro Yuseong-gu Daejeon, \\ 305-700, Republic of Korea
}

Received 13 May 2011; accepted 15 April 2012

\begin{abstract}
Mobile radio frequency identification (RFID) services are expected to be launched in full-scale as a new service option in the telecommunications service market following the development of RFID technology and maturation of the IT infrastructure. Importance of customer loyalty has been widely recognized in business marketing for a long time, and the customer loyalty enhancement strategies for mobile RFID services is of significance to telecommunication carriers in terms of new business value creation. This study identifies the factors affecting customer loyalty for mobile RFID services and presents telecommunication service managers with information useful for improving customer loyalty for related new services. The data was collected from customers with some experience in the use of mobile RFID services through an online survey for an empirical analysis. And the collected data was analysed with structural equation model to verify the cause and effect relationship among perceived quality, switching cost, perceived value, customer satisfaction, switching barrier and customer relationship. The analysis showed that the quality of tag recognition and content quality proved to have a direct impact on the customer satisfaction, whereas connection quality and ease of use would rather indirectly than directly influence customer satisfaction by perceived value. Perceived value and satisfaction affected the loyalty. Adaptation cost affects switching barriers, the higher the switching barriers, the stronger the loyalty. Based on the results of the empirical analysis, practical implications were given. What is more, mobile RFID customers were divided into two groups that are favourably and unfavourably disposed toward the service, and suggested customer loyalty improvement strategies adapted for each group.
\end{abstract}

Keywords: radio frequency identification, mobile RFID, customer loyalty, perceived quality, perceived value, switching cost, switching barrier, customer satisfaction.

Reference to this paper should be made as follows: Park, Y.-J.; Rim, M.-H.; Lee, S.-K. 2013. Factors affecting customer loyalty of mobile RFID services in Korea, Technological and Economic Development of Economy 19(4): 687-705.

\section{JEL Classification: $\mathrm{O} 33$.}

Corresponding author Myung-Hwan Rim

E-mail:mhrim@etri.re.kr 


\section{Introduction}

Radio frequency identification (RFID) is the process and physical infrastructure by which a unique identifier within a predefined protocol definition is transferred from a device to a reader via radio frequency waves (Banks et al. 2007). In recent years, RFID has been applied in wide-ranging areas, from supply chain management to service industries, distribution logistics and manufacturing (Kim et al. 2008). The global RFID market is expected to grow from US $\$ 5.63$ billion in 2010 to US\$ 24.13 billion in 2021 . The RFID reader market for cellular phones, valued at US\$ 0.18 billion in 2010, is forecasted to grow to US\$ 1.6 billion in 2021 (Das, Harrop 2010). A mobile RFID service refers to the service which retrieves the stored information in RFID tags attached to various objects in the surrounding environments and transmits it over wireless internet by using a built-in RFID reader in a mobile handset. The service is currently tried in various fields. For example, it is being used or under the pilot test in retail stores around the world (Boeck et al. 2011); a mobile RFID based tour service system is developed (Hsu, Liao 2011); a customer in a hotel can lock or unlock his room with a mobile device equipped with RFID based near-field communication technology (Sheivachman 2012). Hence, mobile RFID services are now attracting related industries' attention as a new service model of potentially high business value.

In USA, RFID technology is adopted in the federal government-led u-health projects, and an increasingly wide array of services bundles, which combine mobile communications, RFID and wireless internet with other services, are becoming available. In Europe, Nokia and a few other cell phone makers invented 13.55MHz-band handsets applying mobile RFID technology, and are developing various business models based on the technology (Park et al. 2008). In Japan, mobile phone prototypes with capacity to read RFID tags have already been released, and a mobile RFID reader has been commercially rolled out jointly with Hitachi (Hiroyuki 2007). In Korea, mobile RFID services are currently being piloted by its two largest telecoms, SK Telecom and Korea Telecom, and the commercial launch is scheduled for the near future. Mobile RFID services, currently in preparation for commercial launch, are product information or authentication services such as genuine ginseng verification, genuine drug verification, safe taxi, food history, Korean premium beef verification, u-museum, and touch book. More recently, Korean telecom operators have started to design new service models such as McDonald order service, allowing mobile users to order and pay with a RFID tag-attached menu and the RFID reader embedded in the handset. Efforts to expand the range of functions provided by existing mobile RFID services are, therefore, actively underway.

The importance of customer loyalty as a value creation factor has been much stressed in the business marketing field. By deriving factors that affect customer loyalty, developing strategies to increase customer loyalty are topics which attract continuous attention from researchers. Customer loyalty is a matter that deserves serious attention from providers of mobile RFID services because its extent can have a direct influence on the business value of this new service. The practical relevance of identifying factors that induce customer loyalty and suggesting improvement strategies can hardly be overestimated. The knowledge of factors 
affecting customer loyalty toward mobile RFID services, ahead of its commercial roll-out, can help their providers attract loyal customers and ultimately maximize their revenue from this source. The existing literature on this topic is mostly limited to establishing influence factors for customer loyalty and providing strategies for increasing it. Factors that influence customer loyalty can vary depending on whether each type of customer group being favourable or unfavourable toward the offered products or service. The analysis of how influencing factors differ according to the customer type would make the providers of mobile RFID services recognize where service improvement efforts should be focused.

The purpose of this study is to present telecom service managers and providers the implications of how to enhance customer loyalty by drawing the factors that influence customer loyalty toward mobile RFID services. Furthermore, customers of mobile RFID services were divided into two groups, favourably disposed and unfavourably disposed toward them and proposed customer loyalty strategies that are specifically suited to each of the two groups. To achieve these research goals, factors affecting customer loyalty on the basis of the existing literature were selected, a conceptual model was constructed and related hypotheses were formulated. Next, a survey of mobile users with a mobile RFID service experience was conducted. The data with structural equation model was analysed, and the hypotheses were tested. Finally, based on the results of the analysis, we derived implications of practical importance for telecommunications service managers and providers who seek to increase the loyalty to the new services.

\section{Theoretical background}

\subsection{The current status of mobile RFID services in Korea}

The Korean government has recently included RFID services in the list of new engines for economic growth and is currently working on a plan to foster this technology field into a competitive industry. The recent creation of the Mobile RFID Forum is one instance of this government-level effort to ensure a good head start for this technology service. The forum was established to create an innovative service model which delivers a new value to mobile users, by linking RFID infrastructure with the wireless internet infrastructure which is currently used only to provide mobile communications with internet access. The larger purposes of this forum include enhancing the quality of life for Koreans and discovering new industry fields to increase economic value-added and improve national competitiveness. Currently, the Mobile RFID Forum is concentrating its efforts on timely discovery and identification of mobile RFID-related technologies and development of technical standards to enable the early take-off of this sector.

The test runs of various types of mobile RFID services have been performed by SK Telecom and Korea Telecom, the two largest telecom operators of Korea, since 2005. Efforts to discover and develop service models with high revenue potential have been ongoing ever since. The types of mobile RFID services currently in the pilot in Korea are listed in Table 1. 
Table 1. Trial services of mobile RFID in Korea

\begin{tabular}{|c|c|c|}
\hline Providers & Service Name & Provide Service \\
\hline \multirow{10}{*}{$\begin{array}{l}\text { SK } \\
\text { Telecom }\end{array}$} & $\begin{array}{l}\text { Genuine Ginseng } \\
\text { Verification }\end{array}$ & Product verification, products information \\
\hline & u-Portal & Music, movie, game downloads and news feed \\
\hline & Genuine drug Verification & $\begin{array}{l}\text { Verification of a drug's authenticity by reading } \\
\text { embedded RFID tags }\end{array}$ \\
\hline & Safe Taxi & Tracks taxi passenger's travel route \\
\hline & Food History & $\begin{array}{l}\text { Food information including origin and date of } \\
\text { production }\end{array}$ \\
\hline & $\begin{array}{l}\text { Korean Premium Beef } \\
\text { Verification }\end{array}$ & $\begin{array}{l}\text { Beef information including place of origin and date of } \\
\text { slaughtering }\end{array}$ \\
\hline & Touch Book & Provides book summaries and reader reviews \\
\hline & McDonalds Touch Order & Food order placing by tagging the menu \\
\hline & U-Museum & $\begin{array}{l}\text { Download and E-mail transmission of exhibits } \\
\text { information }\end{array}$ \\
\hline & $\mathrm{u}$-PIFF & $\begin{array}{l}\text { Retrieves information on Pusan International Film } \\
\text { Festival }\end{array}$ \\
\hline \multirow{6}{*}{$\begin{array}{l}\text { Korea } \\
\text { Telecom }\end{array}$} & Wine information Service & Provision of the detailed data on wine \\
\hline & Indoor Navigation Service & Guides users to their desired destinations using RFID \\
\hline & Shopping Guide Service & $\begin{array}{l}\text { A personalized shopping guide service, using } \\
\text { customer-provided information on shopping } \\
\text { preferences and goals }\end{array}$ \\
\hline & Sending My Position Service & $\begin{array}{l}\text { Sends user location information via MMS to friends in } \\
\text { complicated environments }\end{array}$ \\
\hline & U-Game Service & Mission or event-based gaming assistance \\
\hline & $\begin{array}{l}\text { Busan/Daegu City Tour } \\
\text { Service }\end{array}$ & Useful information about touring city using RFID \\
\hline
\end{tabular}

Note: The data taken from Yoon $(2007,2010)$ and Kim $(2007)$ were reedited for the purposes of this paper.

\subsection{Perceived quality in mobile RFID services}

Perceived quality defines customers' intangible perceptions or judgments of the overall quality or superiority of a product or service (Ramaseshan, Tsao 2007). Perceived quality, known as a factor that influences the value and satisfaction a customer perceives toward a product or service, can have the following specific characteristics, when applied to a mobile RFID service: The first is the quality of tag recognition. As the mobile RFID service is an information retrieval service gaining stored information from RFID tag on surrounding objects, the accuracy of tag recognition, recognition rate, and distance are the most important quality factors (Park et al. 2008).

Second, as the tag information obtained is transmitted over wireless internet, the quality of connection to the wireless internet is also an important determinant of quality (Park et al. 2008). Chae et al. (2002), for instance, found that the quality of connection between RFID system and wireless internet played an essential role in customers' quality perception. 
Third, ease of use, a quality factor believed to have important influence on satisfaction of information system users (Rai et al. 2002; DeLone, McLean 2004), is likely to also have an effect on perceived quality of a mobile RFID service. Hong et al. (2006), in their study on mobile data services, found empirical evidence that ease of use decisively affected a potential user's intention to actually use the service.

Finally, the service reading an RFID tag provides a user with the relevant content over wireless internet. The content should be accurate, easy to understand and up-to-date, so that their quality can be a potentially important factor shaping perceived quality of the service (Chae et al. 2002; DeLone, McLean 2004; Park et al. 2008). Prior studies on perceived quality are listed in Table 2.

Table 2. Prior studies on quality factors

\begin{tabular}{lcccc}
\hline Researcher & Tag Recognition & Connection & Ease of use & Content \\
\hline Chae et al. $(2002)$ & & $\sqrt{ }$ & & $\sqrt{ }$ \\
\hline Rai et al. $(2002)$ & & $\sqrt{ }$ & \\
\hline DeLone, McLean (2004) & & $\sqrt{ }$ & \\
\hline Hong et al. $(2006)$ & $\sqrt{ }$ & $\sqrt{ }$ & & $\sqrt{ }$ \\
\hline Park et al. $(2008)$ & & & & \\
\hline
\end{tabular}

\subsection{Switching cost and switching barriers in mobile RFID services}

Porter (1998) defined switching cost as one-time cost facing the buyer when switching from one supplier's product to another's. Switching cost includes not only objectively measurable monetary cost but also the psychological effect of becoming a customer of a new firm, and the time and effort involved in buying a new brand (Klemperer 1995; Kim et al. 2003; Aydin, Ozer 2005a). The mobile RFID service, a new technology service with RFID, requires adaptation cost, and move-in cost. The adaptation cost is related to the effort to adapt to a new service, and the move-in cost incurs in this transition. In an empirical study of switching cost, Kim et al. (2004) classified perceived cost in mobile telecommunications services into three types: loss cost, adaptation cost and move-in cost. They, meanwhile, defined loss cost as perceived loss in social status and performance associated with switching from an existing carrier to a new one. However, loss cost is not applicable to the mobile RFID service because it results not from the loss of social status and performance connected with the secession from existing carrier but from switching to a new service. Thus, the categories of perceived cost were limited to adaptation cost and move-in cost.

Switching barriers may be defined as 'the consumer's assessment of the resources and opportunities needed to perform the switching act, or alternatively, the constraints that prevent the switching act' (Bansal, Taylor 1999; Ranaweera, Prabhu 2003). Kim et al. (2004) defined switching barriers as the 'economic and psychological difficulty perceived by customer, when switching carriers'. In the context of the mobile RFID service, switching barriers were defined as constraints related to switching or subscribing to the service, in other words, the perceived economic and psychological difficulty associated with adopting a new service. 
Shin and Kim (2008), meanwhile, reported, in their empirical study on mobile services, the existence of a causal relationship between switching cost and switching barriers in which the former influence the latter. Noteworthy previous studies on switching cost and switching barriers are shown in Table 3.

Table 3. Prior studies on switching cost and switching barriers

\begin{tabular}{lcc}
\hline Researcher & Switching Cost & Switching Barriers \\
\hline Klemperer (1995) & $\sqrt{ }$ & \\
\hline Porter (1998) & $\sqrt{ }$ & \\
\hline Kim et al. (2003) & $\sqrt{ }$ & $\sqrt{ }$ \\
\hline Kim et al. (2004) & $\sqrt{ }$ & \\
\hline Aydin, Ozer (2005a) & $\sqrt{ }$ \\
\hline Shin, Kim (2008) & $\sqrt{ }$ & \\
\hline
\end{tabular}

\subsection{Perceived value, customer satisfaction and loyalty in mobile RFID services}

According to Zeithaml (1988), perceived value is assumed to involve consumer's assessment of the ratio of perceived benefits to perceived cost. And Yang and Peterson (2004) state that perceived value results from an evaluation of the relative rewards and sacrifices associated with the offering. Fornell et al. (1996) considered perceived value a major determinant of customer satisfaction and defined it as the perceived level of product quality relative to the price paid. They analysed causal relationships among perceived value, satisfaction, and loyalty. Based on the study of Fornell et al. (1996), perceived value is defined as the perceived level of a mobile RFID service quality relative to the price paid.

In the business marketing field, the empirical researches that try to unveil the antecedents and consequences of customer satisfaction have been extensively handled by many scholars. Customer satisfaction, according to Oliver (1997), is customer reaction to the state of fulfilment, and customer judgment of the fulfilled state. As for Lin and Wang (2006), they described customer satisfaction with regard to $\mathrm{m}$-commerce as the summary affective response or feeling of a customer in relation to her/his experience with all aspects that were developed by an m-service to market its products and services. They revealed that there existed the causal relationship among perceived value, customer satisfaction and loyalty. Rooted in Lin and Wang's definition, customer satisfaction was redefined as the summary affective response or feeling of a potential customer in relation to her/his experience with all aspects developed by a mobile RFID service.

Customer loyalty constitutes an important area of research in marketing literature, and can be a core objective for telecom operators. Kim et al. (2004), in their empirical analysis which found that customer loyalty is influenced by customer satisfaction, regarded customer loyalty in telecommunications services as the combination of customers' favourable attitude toward a service and intention to re-purchase this service. Turel and Serenko (2006) stated that in the mobile services context, loyalty is defined as a favourable attitude toward a specific service provider that leads to a combination of repurchase likelihood of additional services from the same provider and tolerance to price increase. They also attested the existence of a 
causal relationship among perceived value, customer satisfaction and customer loyalty. On the basis of these preceding works, customer loyalty in mobile RFID services was defined as a favourable attitude toward the service resulting in the willingness to reuse it and recommend it to others. Prior studies on perceived value, customer satisfaction and loyalty are listed in Table 4.

Table 4. Prior studies on perceived value, satisfaction and loyalty of customer

\begin{tabular}{lccc}
\hline Researcher & Perceived Value & Satisfaction & Loyalty \\
\hline Zeithaml (1988) & $\sqrt{ }$ & & \\
\hline Fornell et al. (1996) & $\sqrt{ }$ & $\sqrt{ }$ & $\sqrt{ }$ \\
\hline Oliver (1997) & & $\sqrt{ }$ & \\
\hline Kim et al. (2004) & & $\sqrt{ }$ & $\sqrt{ }$ \\
\hline Yang, Peterson (2004) & $\sqrt{ }$ & & \\
\hline Lin, Wang (2006) & $\sqrt{ }$ & $\sqrt{ }$ & $\sqrt{ }$ \\
\hline Turel, Serenko (2006) & $\sqrt{ }$ & $\sqrt{ }$ & $\sqrt{ }$ \\
\hline
\end{tabular}

\section{Research model and hypotheses}

To determine factors that affect customers' loyalty toward a mobile RFID service, a research model based on the existing literature was set (Fig. 1): The higher customers' perceived quality, the greater their perceived value and satisfaction; the greater the switching cost, the higher the switching barrier; the greater their perceived value, satisfaction and switching barrier, the higher their loyalty to a mobile RFID service (Kim et al. 2004). The influence of perceived quality on perceived value and customer satisfaction has been confirmed through numerous empirical studies. For example, Hellier et al. (2003), in their investigation of factors affecting customers' repurchase intention in insurance services, analysed that perceived value was effectively influenced by perceived quality. In a study on the Turkish mobile telephone market, Aydin and Ozer (2005b) found that perceived quality had a significant effect on customer satisfaction. Turel and Serenko (2006) verified that concerning mobile services in Canada, perceived quality affected perceived value and customer satisfaction. Through an empirical analysis, Park et al. (2008) showed that perceived quality factors impacted on customer satisfaction. Drawing on the above-described existing literature, the following hypotheses (H1 and $\mathrm{H} 2$ ) were formulated:

H1. Perceived quality has a positive effect on perceived value.

H1.1 The quality of RFID tag recognition has a positive effect on perceived value.

H1.2 The quality of connection has a positive a positive effect on perceived value.

H1.3 Ease of use has a positive a positive effect on perceived value.

H1.4 Content quality has a positive effect on perceived value.

H2. Perceived quality has a positive effect on satisfaction.

H2.1 The quality of RFID tag recognition has a positive effect on satisfaction.

H2.2 The quality of connection has a positive a positive effect on satisfaction.

$\mathrm{H} 2.3$ Ease of use has a positive a positive effect on satisfaction.

$\mathrm{H} 2.4$ Content quality has a positive a positive effect on satisfaction. 


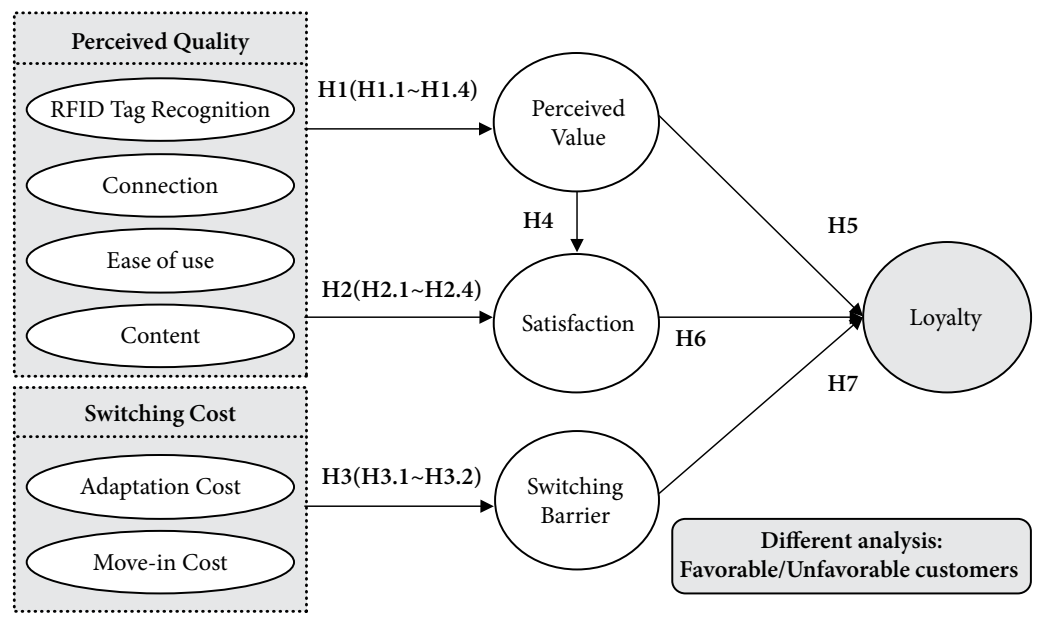

Fig. 1. Research model

In empirical studies on the causal relationship between perceived cost and switching barriers, Kim et al. (2004) found that switching barriers in mobile telecommunications services were affected by perceived switching cost. Shin and Kim (2008) reached similar results. They proved that switching barriers were influenced by switching cost perceived by customers in their empirical investigation of mobile services. Based on these studies, the following hypotheses (H3) were formulated:

H3. Switching cost has a positive effect on switching barriers.

H3.1 Adaptation cost has a positive effect on switching barriers.

H3.2 Move-in cost has a positive effect on switching barriers.

The existence of causal relationships among perceived value, customer satisfaction and loyalty has been empirically verified in various service sectors. In a study investigating the relationship of perceived value, customer satisfaction and loyalty in online banking services, Yang and Peterson (2004) advanced that perceived value positively impacted on both customer satisfaction and loyalty, and that customer satisfaction, in turn, influenced positively customer loyalty. Lai (2004) reported that customers' satisfaction with short message services (SMS) is affected by their perceived value. Lin and Wang (2006) reached a similar conclusion in their study of factors affecting customer loyalty in mobile commerce contexts. They stated that perceived value influenced both customer satisfaction and loyalty, while customers' satisfaction also affected their level of loyalty. In the study on customer satisfaction with Canadian mobile services, Turel and Serenko (2006) empirically verified the thesis that customer satisfaction was influenced by perceived value, and customer loyalty was positively affected by customer satisfaction. Based on the above-discussed existing literature, three hypotheses ( $\mathrm{H} 4-\mathrm{H} 6)$ on perceived value, customer satisfaction and loyalty were set up.

The causal relationship between switching barriers and customer loyalty in the context of telecommunications services was explored by Kim et al. (2004). They found that the higher the switching barriers, the stronger the customer loyalty toward services or service providers: In a situation where competitive services or service providers exist, high switching barriers can 
increase customers' loyalty through the customer lock-in effect. Hence, the hypothesis H7 was established on the relationship between switching barriers and customer loyalty.

H4. Perceived value has a positive effect on customer satisfaction.

H5. Perceived value has a positive effect on customer loyalty.

H6. Satisfaction has a positive effect on customer loyalty.

H7. Switching barriers have a positive effect on customer loyalty.

\section{Methodology}

\subsection{Data, sample and measurement of factors}

While the research factors and items were chosen largely based on prior studies, the measurement items were appropriately modified and redefined to suit the purposes of this study. All survey items were measured using a five-point scale ranging from "very low" to "very high". The measurement items used in the survey were tested through a preliminary survey, which was conducted with technological experts and business professionals involved in the mobile RFID field. After necessary modifications, 23 measurement items were finally selected (Table 5).

Through online survey, data were collected from customers with some experience in the use of mobile RFID pilot services. The mobile RFID pilot service surveyed covers 16 services including genuine ginseng verification and $\mathrm{u}$-Portal provided by SK Telecom and Korea Telecom, as shown in Table 1 . Of a total of 350 responses returned, 317 were retained, after discarding incomplete or otherwise invalid responses.

In the experience of mobile RFID service, the respondents underwent average 5 or more pilot services; $43.6 \%$ of them tested the service 5 to 10 times, followed by 5 times or less (41.4\%), 11 to 15 times (7.7\%), and 16 times or more (7.3\%). In WTP (willingness to pay) for the service charge, US\$ 2.5 or less $(63.8 \%)$ was predominant, followed by US\$ 2.5 to US\$ 5 (21\%), US\$ 5 to US\$ 7.5 (7.2\%), US\$ 7.5 to US\$ 10 (4.6\%), and US\$ 12 or more (3.4\%).

The socio-demographic characteristics of the sample were as follows: male respondents (61.2\%) largely exceeded women (38.8\%) in number. People aged 20 to 29 years $(42.3 \%)$ and 30 to 39 years $(31.2 \%)$ represented the majority of the sample. By educational level, college graduates and above accounted for an overwhelming majority of $74.4 \%$, and by employment status, $63.1 \%$ of the total respondents were employed. By income, earners of US\$1,600 to 2,500 a month made up the largest group (43.9\%).

Table 5. Factors and measurement items

\begin{tabular}{|c|c|c|}
\hline Factors & Measurement Items & Related Studies \\
\hline \multirow{3}{*}{$\begin{array}{l}\text { Tag } \\
\text { recognition }\end{array}$} & Accuracy of tag reading & \multirow{3}{*}{ Park et al. (2008) } \\
\hline & Distance of tag reading & \\
\hline & Degree rate of tag recognition & \\
\hline \multirow{2}{*}{ Connection } & $\begin{array}{l}\text { The mobile RFID service system is stable, and errors are } \\
\text { few and infrequent }\end{array}$ & \multirow{2}{*}{$\begin{array}{l}\text { Park et al. }(2008) \\
\text { Chae et al. }(2002)\end{array}$} \\
\hline & Cn2 Quick response to RFID tags and short download time & \\
\hline
\end{tabular}


Continued Table 5

\begin{tabular}{|c|c|c|}
\hline Factors & Measurement Items & Related Studies \\
\hline \multirow{2}{*}{ Ease of use } & Ea1 The mobile RFID service system is easy to use & \multirow{2}{*}{$\begin{array}{l}\text { Hong et al. (2006); } \\
\text { Wang, Liao (2007) }\end{array}$} \\
\hline & The mobile RFID service system is user-friendly & \\
\hline \multirow{3}{*}{ Content } & Co1 The content delivered is accurate & \multirow{3}{*}{$\begin{array}{l}\text { Wang, Liao (2007); } \\
\text { Negash et al. (2003) }\end{array}$} \\
\hline & Co2 The content delivered is up to date & \\
\hline & The content is clear and understandable & \\
\hline \multirow{2}{*}{$\begin{array}{l}\text { Adaptation } \\
\text { cost }\end{array}$} & $\begin{array}{ll}\text { Ad1 Inconvenience of having to learn to use a mobile } \\
\text { RFID service }\end{array}$ & \multirow[t]{2}{*}{ Kim et al. (2004) } \\
\hline & Ad2 Need to search for information on mobile RFID services & \\
\hline \multirow{2}{*}{ Move-in cost } & Mo1 Cost of replacing a mobile RFID device & \multirow{2}{*}{ Kim et al. (2004) } \\
\hline & Mo2 Cost of using mobile internet & \\
\hline \multirow{2}{*}{$\begin{array}{l}\text { Switching } \\
\text { barrier }\end{array}$} & $\begin{array}{ll}\text { Sw1 } & \begin{array}{l}\text { Economic loss associated with switching mobile RFID } \\
\text { services }\end{array}\end{array}$ & \multirow{2}{*}{$\begin{array}{l}\text { Kim et al. (2004) } \\
\text { Shin, Kim (2008) }\end{array}$} \\
\hline & $\begin{array}{ll}\text { Sw2 } & \text { Psychological burden associated with switching mobile } \\
\text { RFID services }\end{array}$ & \\
\hline \multirow{2}{*}{$\begin{array}{l}\text { Perceived } \\
\text { value }\end{array}$} & Pv1 $\quad$ Mobile RFID services are very valuable & \multirow{2}{*}{ Lin, Wang (2006) } \\
\hline & Pv2 Mobile RFID services are good value for money & \\
\hline \multirow{3}{*}{ Satisfaction } & Overall satisfaction with the mobile RFID service & \multirow{5}{*}{$\begin{array}{l}\text { Park et al. (2008); } \\
\text { Fornell et al. }(1996) \text {; } \\
\text { Turel, Serenko } \\
\text { (2006); Joo, Sohn } \\
\text { (2008) }\end{array}$} \\
\hline & Degree of expectancy disconfirmation & \\
\hline & Performance versus ideal mobile RFID services & \\
\hline \multirow{2}{*}{ Loyalty } & Lo1 Intention to reuse the mobile RFID service & \\
\hline & Lo2 Intention to recommend the mobile RFID service & \\
\hline
\end{tabular}

\subsection{Measurement and structural models}

A confirmatory factor analysis (CFA) was performed to test the adequacy of the measurement model. The adequacy of the measurement models was evaluated on the criteria of overall fit with the data, reliability, convergent validity, and discriminant validity (Chiou 2004).

Seven common model-fit measures were used to assess the measurement model's overall goodness of fit: the ratio of $\chi^{2}$ to degrees-of-freedom (d.f.), adjusted goodness-of-fit index (AGFI), normalized fit index (NFI), non-normalized fit index (NNFI), comparative fit index (CFI), relative fit index (RFI) and root mean square error of approximation (RMSEA)(Lin, Wang 2006). The reliability of the factors was estimated through internal consistency. The internal consistency (IC) of the measurement model was calculated with the Eq. (1) (Fornell, Larcker 1981). An IC coefficient of 0.7 or higher is considered as a satisfactory level of internal consistency.

$$
\mathrm{IC}=\left(\sum \lambda_{i}\right) 2 /\left[\left(\sum \lambda_{i}\right) 2+\sum \operatorname{var}\left(\varepsilon_{i}\right)\right]
$$

$\lambda_{i}$ : The loading of each of the measurement items on its corresponding factor, $\operatorname{var}\left(\varepsilon_{i}\right)=1-\lambda_{i}^{2}$.

Convergent validity of the factors was estimated with average variance extracted (AVE). The AVE was calculated by Eq. (2) (Fornell, Larcker 1981). The AVE was above the recom- 
mended 0.5 level, which meant that more than one-half of the variances observed in the items were accounted for by their hypothesized factors (Lin, Wang 2006). Discriminant validity is the degree to which items differentiate between factors, or measure different factors. To test discriminant validity, the shared variances were compared to the factors with the AVE of the individual factors (Fornell, Lacker 1981; Lin, Wang 2006).

$$
\mathrm{AVE}=\left(\sum \lambda_{i} 2\right) /\left[\left(\sum \lambda_{i} 2\right)+\sum \operatorname{var}\left(\varepsilon_{i}\right)\right]
$$

$\lambda_{i}$ : The loading of each of the measurement items on its corresponding factor, $\operatorname{var}\left(\varepsilon_{i}\right)=1-\lambda_{i}^{2}$.

The proposed research model was tested by performing structural equation model (SEM) with the maximum likelihood estimation method using AMOS 5.0. The SEM is a most widely used technique for testing and estimating causal relations between latent factors, especially, in empirical studies of social science. A similar set of fit indices was used to prove the structural model: the ratio of $\chi^{2}$ to degrees-of-freedom (d.f.), AGFI, NFI, NNFI, CFI, RFI and RMSEA.

\subsection{Analysis of customer types}

Gerpott et al. (2001) classified customers into four different categories by analysing a matrix between loyalty and satisfaction: optimistic customers, impressed customers, disappointed customers, pessimistic customers. In this study, these four classifications were simplified into two categories (Fig. 2). One group, 'favourable customers', including optimistic customers and impressed customers, is characterized by a positive perception and attitude, and higher loyalty to the mobile RFID services. The other group, 'unfavourable customers', comprising disappointed customers and pessimistic customers, is sceptical and not loyal to the services. A total of 317 samples were used in the global model analysis. Among them 'favourable customer group' whose loyalty for mobile RFID service is higher than 3 (the medium value of 5 -point Likert Scale) is 124, and 'unfavourable customer group' whose loyalty is lower than 3 is 183 . Here can be seen an attempt to analyse how the factors affecting customers' loyalty to mobile RFID services are different between these two groups.

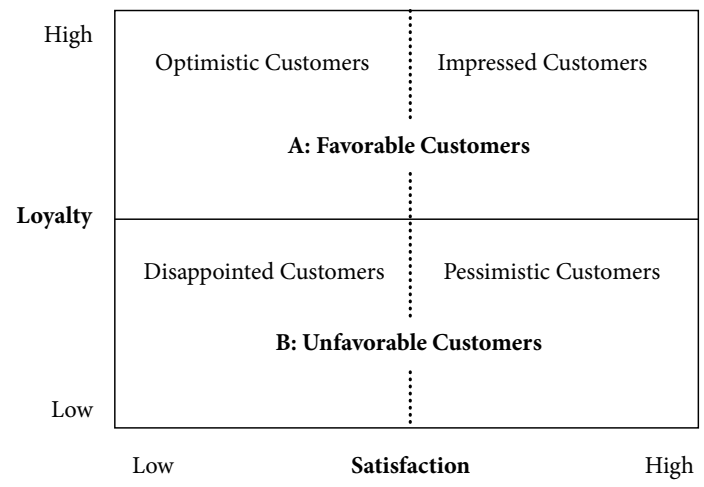

Fig. 2. Analysis of customer types 


\section{Results}

\subsection{Results of measurement model testing}

As shown in Table 6, all fit indices estimated for the measurement model met their respective recommended values, and the model proved to be valid.

Table 6. Results of fit indices for the measurement model

\begin{tabular}{lcc}
\hline Fit index & Recommended value & Measurement model \\
\hline$\chi^{2 / \text { d.f. }}$ & $\leq 3.00$ & 2.71 \\
\hline AGFI & $\geq 0.80$ & 0.89 \\
\hline NFI & $\geq 0.90$ & 0.95 \\
\hline NNFI & $\geq 0.90$ & 0.95 \\
\hline CFI & $\geq 0.90$ & 0.97 \\
\hline RFI & $\geq 0.90$ & 0.92 \\
\hline RMSEA & $\leq 0.08$ & 0.07 \\
\hline
\end{tabular}

Thus the testing of reliability, convergent validity, and discriminant validity was proceeded. The results of these tests were as follows (Table 7): all factors exceeded 0.7 (recommended value $>0.7$ ) in internal consistency, which attested to a good level of reliability. AVE values for all factors were greater than 0.5 (recommended value $>0.5$ ), which showed convergent validity. The discriminant validity analysis also revealed (Table 8 ) that AVE square roots values of the diagonal were greater than all other values, which proved its validity.

Table 7. Results of reliability and convergent validity of factors

\begin{tabular}{lcl}
\hline Factor & Internal Consistency & AVE \\
\hline Tag Recognition (C1) & 0.912 & 0.776 \\
\hline Connection (C2) & 0.883 & 0.791 \\
\hline Ease of use (C3) & 0.889 & 0.801 \\
\hline Content (C4) & 0.920 & 0.793 \\
\hline Adaptation Cost (C5) & 0.736 & 0.643 \\
\hline Move-in Cost (C6) & 0.886 & 0.796 \\
\hline Perceived Value (C7) & 0.903 & 0.824 \\
\hline Customer Satisfaction (C8) & 0.904 & 0.758 \\
\hline Switching Barriers (C9) & 0.788 & 0.703 \\
\hline Customer Loyalty (C10) & 0.914 & 0.841 \\
\hline
\end{tabular}


Table 8. Results of discriminant validity testing

\begin{tabular}{lcccccccccc}
\hline Factors & C1 & C2 & C3 & C4 & C5 & C6 & C7 & C8 & C9 & C10 \\
\hline C1 & $\mathbf{0 . 8 8 1}$ & & & & & & & & & \\
\hline C2 & 0.556 & $\mathbf{0 . 8 8 9}$ & & & & & & & & \\
\hline C3 & 0.560 & 0.465 & $\mathbf{0 . 8 9 5}$ & & & & & & & \\
\hline C4 & 0.534 & 0.547 & 0.568 & $\mathbf{0 . 8 9 1}$ & & & & & & \\
\hline C5 & -0.343 & -0.267 & -0.287 & -0.387 & $\mathbf{0 . 8 0 2}$ & & & & & \\
\hline C6 & 0.197 & 0.117 & 0.291 & 0.262 & -0.681 & $\mathbf{0 . 8 9 2}$ & & & & \\
\hline C7 & 0.666 & 0.730 & 0.599 & 0.619 & -0.422 & 0.120 & $\mathbf{0 . 9 0 8}$ & & & \\
\hline C8 & 0.788 & 0.770 & 0.788 & 0.750 & -0.415 & 0.191 & 0.791 & $\mathbf{0 . 8 7 1}$ & & \\
\hline C9 & -0.307 & -0.278 & -0.238 & -0.251 & 0.798 & 0.785 & -0.341 & -0.348 & $\mathbf{0 . 8 3 8}$ & \\
\hline C10 & 0.200 & 0.274 & 0.381 & 0.390 & -0.138 & 0.121 & 0.786 & 0.748 & 0.728 & $\mathbf{0 . 9 1 7}$ \\
\hline
\end{tabular}

\subsection{Results of structural model testing}

To test the conceptual model and hypotheses suggested, the validity of the structural model was evaluated. As shown in Table 9, all fit indices for the structural model met the recommended value, which proved to be valid. The results of structural model testing are presented in the diagram in Fig. 3.

Table 9. Results of fit indices for the structural model

\begin{tabular}{lcc}
\hline Fit index & Recommended value & Measurement model \\
\hline$\chi 2 /$ d.f. & $\leq 3.00$ & 2.35 \\
\hline AGFI & $\geq 0.80$ & 0.82 \\
\hline NFI & $\geq 0.90$ & 0.91 \\
\hline NNFI & $\geq 0.90$ & 0.93 \\
\hline CFI & $\geq 0.90$ & 0.95 \\
\hline RFI & $\geq 0.90$ & 0.90 \\
\hline RMSEA & $\leq 0.08$ & 0.07 \\
\hline
\end{tabular}

All hypotheses were accepted except H1.1, H1.4, H2.2, H2.3 and H3.2. The quality of tag recognition (estimate $=0.464, \mathrm{p}<0.01$ ) and content quality (estimate $=0.360, \mathrm{p}<0.01$ ) proved to have a direct impact on the customer satisfaction. The quality of connection (estimate $=0.713$, $\mathrm{p}<0.01$ ) and ease of use (estimate $=0.267, \mathrm{p}<0.05$ ), meanwhile, were found to affect perceived value but have no direct relation with satisfaction. These results will mean that connection quality and ease of use would rather indirectly than directly influence customer satisfaction by perceived value (estimate $=0.333, \mathrm{p}<0.01$ ) which has a direct effect on satisfaction; as perceived value (estimate $=0.481, \mathrm{p}<0.01$ ) and satisfaction (estimate $=0.265, \mathrm{p}<0.05)$ affected the loyalty, it is significant to manage perceived quality factors (i.e. quality of tag recognition, connection quality, ease of use, and content quality) which is the antecedent of the two. In the case of switching cost, while adaptation cost affects switching barriers (estimate $=0.924, \mathrm{p}<0.01$ ), move-in cost had no significant effect on them; the higher the switching barriers, the stronger the loyalty (estimate $=0.163, \mathrm{p}<0.05)$. Detailed results of hypothesis testing are given in Table 10 . 


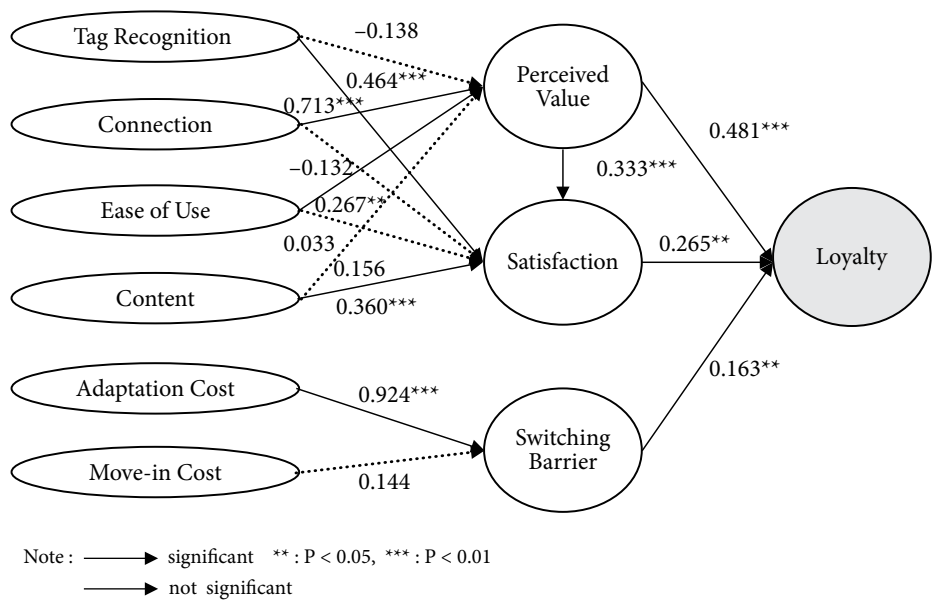

Fig. 3. Results of structural model testing

Table 10. Results of research hypothesis $(\mathrm{H} 1-\mathrm{H} 7)$ testing

\begin{tabular}{|c|c|c|c|c|c|c|}
\hline Path & Нypc & thesis & Estimate & S.E. & $\mathrm{t}$ value. & Result \\
\hline Tag Recognition $\rightarrow$ Perceived Value & \multirow{4}{*}{$\mathrm{H} 1$} & H1.1 & -0.138 & 0.191 & -0.726 & Reject \\
\hline Connection $\rightarrow$ Perceived Value & & H1.2 & $0.713^{\star * *}$ & 0.247 & 2.882 & Accept \\
\hline Ease of use $\rightarrow$ Perceived Value & & H1.3 & $0.267^{\star *}$ & 0.115 & 2.329 & Accept \\
\hline Content $\rightarrow$ Perceived Value & & H1.4 & 0.156 & 0.162 & 0.965 & Reject \\
\hline Tag Recognition $\rightarrow$ Satisfaction & \multirow{4}{*}{$\mathrm{H} 2$} & $\mathrm{H} 2.1$ & $0.464^{\star * *}$ & 0.123 & 3.782 & Accept \\
\hline Connection $\rightarrow$ Satisfaction & & $\mathrm{H} 2.2$ & -0.132 & 0.165 & -0.800 & Reject \\
\hline Ease of use $\rightarrow$ Satisfaction & & $\mathrm{H} 2.3$ & 0.033 & 0.075 & 0.444 & Reject \\
\hline Content $\rightarrow$ Satisfaction & & $\mathrm{H} 2.4$ & $0.360^{* * *}$ & 0.100 & 3.591 & Accept \\
\hline Adaptation Cost $\rightarrow$ Switching Barriers & \multirow{2}{*}{$\mathrm{H} 3$} & H3.1 & $0.924^{\star \star *}$ & 0.165 & 5.604 & Accept \\
\hline Move-in Cost $\rightarrow$ Switching Barriers & & H3.2 & 0.144 & 0.085 & 1.626 & Reject \\
\hline Perceived Value $\rightarrow$ Satisfaction & \multicolumn{2}{|c|}{$\mathrm{H} 4$} & $0.333^{\star * *}$ & 0.062 & 5.358 & Accept \\
\hline Perceived Value $\rightarrow$ Loyalty & \multicolumn{2}{|c|}{ H5 } & $0.481^{\star \star \star}$ & 0.113 & 4.269 & Accept \\
\hline Satisfaction $\rightarrow$ Loyalty & \multicolumn{2}{|c|}{ H6 } & $0.265^{\star *}$ & 0.129 & 2.054 & Accept \\
\hline Switching Barriers $\rightarrow$ Loyalty & \multicolumn{2}{|c|}{$\mathrm{H} 7$} & $0.163^{\star *}$ & 0.067 & 1.982 & Accept \\
\hline
\end{tabular}

\subsection{Results of difference analysis by customer type}

In this study, customers were divided into two groups according to their attitude toward mobile RFID services: favourable customers and unfavourable customers. In order to analyse whether there is any difference between these two groups, in terms of factors affecting the loyalty, an analysis of structural equation model on two sub-structural models was performed. As can be seen from Table 11, all fit indices for two sub-structural models met the recommended value and structural equation model proved to be valid. 
The results of testing the two sub-structural models are respectively shown in diagrams in Fig. 4. In the favourable customers group, the quality of tag recognition proved to have a direct effect on satisfaction (estimate $=0.288, \mathrm{p}<0.1$ ), and connection quality had no influence on either perceived value or satisfaction. Ease of use (estimate $=0.396, p<0.1$ ) and content quality (estimate $=0.553, \mathrm{p}<0.1$ ), while they did impact on perceived value of a mobile RFID service, appeared to have no significant effect on satisfaction, suggesting that their influence on satisfaction may be indirect through perceived value.

As for the unfavourable customers group, unlike with the favourable customers group, tag recognition quality (estimate $=0.441, \mathrm{p}<0.01$ ) and content quality (estimate $=0.274$, $\mathrm{p}<0.05$ ) had an influence on satisfaction, but not on perceived value; connection quality (estimate $=0.634, \mathrm{p}<0.05$ ) and ease of use (estimate $=0.277, \mathrm{p}<0.1)$ had a significant effect on perceived value, but not on satisfaction, indicating that their influence on satisfaction is indirect through perceived value (estimate $=0.344, \mathrm{p}<0.01$ ) which directly affects satisfaction.

Table 11. Results of fit indices for two sub-structural models

\begin{tabular}{lccc}
\hline Fit index & Recommended value & Subgroup 1 model & Subgroup 2 model \\
\hline$\chi 2 /$ d.f. & $\leq 3.00$ & 2.40 & 2.45 \\
\hline AGFI & $\geq 0.80$ & 0.80 & 0.81 \\
\hline NFI & $\geq 0.90$ & 0.90 & 0.91 \\
\hline NNFI & $\geq 0.90$ & 0.92 & 0.90 \\
\hline CFI & $\geq 0.90$ & 0.91 & 0.92 \\
\hline RFI & $\geq 0.90$ & 0.90 & 0.91 \\
\hline RMSEA & $\leq 0.08$ & 0.06 & 0.07 \\
\hline
\end{tabular}

Note: 'Subgroup 1 model' refers to the sub-structural model for favourable customers group $(\mathrm{n}=124)$, 'Subgroup 2 model' refers to the sub-structural model for unfavourable customers group $(\mathrm{n}=193)$.

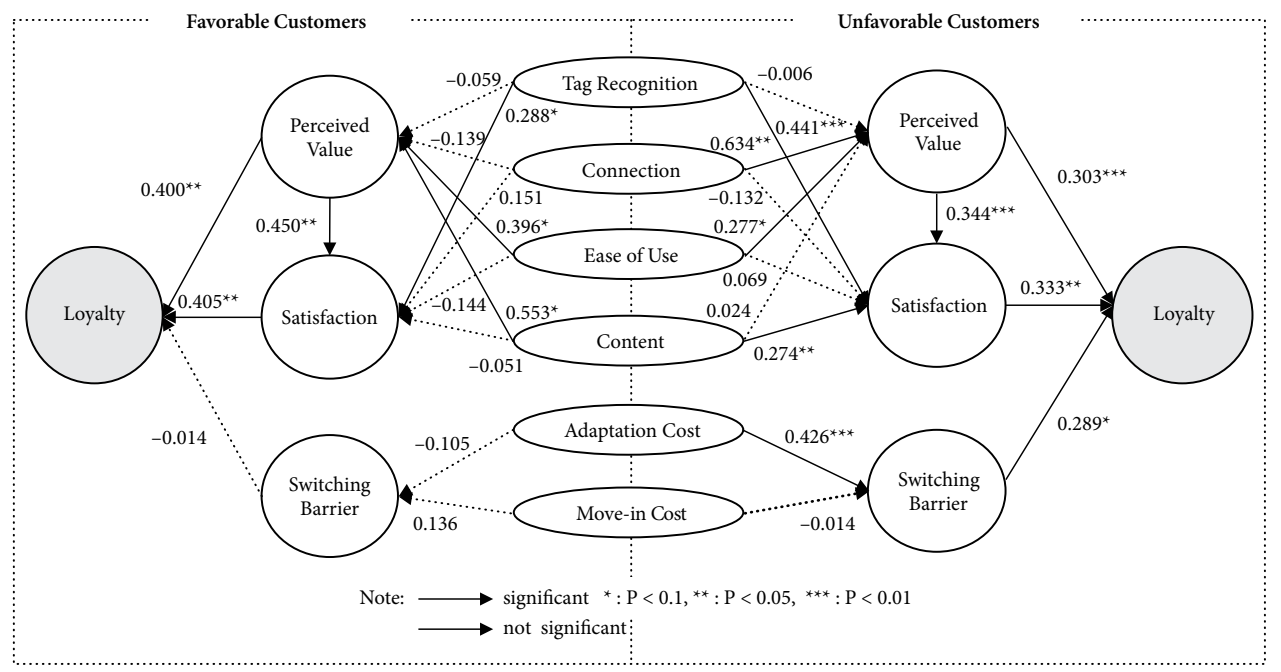

Fig. 4. Results of testing the sub-structural model (favorable/unfavorable customers) 
As for perceived value and satisfaction, they influenced customers' loyalty in both favourable and unfavourable customers groups, which recognized the importance of managing perceived quality that affect these two factors.

Among favourable customers, switching cost had no influence on switching barriers, nor did switching barriers affect the loyalty. This suggest that favourable customers to mobile RFID services are generally unaffected by switching cost or barriers to a new service. On the other hand, among unfavourable customers, adaptation cost proved to have an effect on switching barriers (estimate $=0.426, \mathrm{p}<0.01$ ), and switching barriers, in turn, impacted on the loyalty (estimate $=0.289, \mathrm{p}<0.1$ ), which indicate that managing adaptation cost, an influence factor of switching barriers, is required.

\section{Implications and conclusions}

This study has attempted to find strategies to enhance the loyalty of customers to mobile RFID services by identifying the factors that affect their loyalty. The implications of the results of this empirical analysis for telecommunications service managers and providers are as follows: First, perceived value and satisfaction were the two influence factors for customer loyalty to mobile RFID services. Among perceived quality factors that are antecedents of perceived value and satisfaction, tag recognition and content were direct influence factors on customer satisfaction; connection quality and ease of use indirect influence factors on it by means of the perceived value. This means that in order to increase customers' perceived value and satisfaction influencing their loyalty to the services, it may be necessary for service providers to constantly strive for the improvement of perceived quality factors: they must make special exertions to enhance the quality of tag recognition, connection quality, ease of use, and content quality and to step up R\&D for both related hardware and software.

Second, switching barrier was affected by adaptation cost. This implies that service providers must manage adaptation cost in order to motivate customers to switch over to a new mobile RFID service. When customers try to adopt or switch to a new service, they tend to be reluctant to change on account of adaptation cost for learning and searching information to become familiar with the service. Hence, the policy to eliminate obstacles to learning and information search is essential so as to promote and facilitate the use of mobile RFID services.

Third, the analysis of each customer type revealed that, in the case of favorable customers group, tag recognition quality directly affected satisfaction, whereas ease of use and content quality indirectly influenced it by the intermediary of perceived value. Meanwhile, among unfavourable customers, both tag recognition quality and content quality had a direct impact on their satisfaction. But the quality of connection and ease of use indirectly affected satisfaction by perceived value. Perceived quality factors which influence perceived value and satisfaction, therefore, differed according to each customer type. And switching cost had no influence on switching barriers among favourable customers group, while adaptation cost appeared to have an effect on switching barriers. In other words, depending on the type of customers group, there existed a difference between switching cost and switching barriers: Though no significant difference was found between the two groups in terms of influence of perceived value and satisfaction on customers' loyalty, there was a clear difference in terms of influence of switching barriers on it. 
These results suggest that differentiated service improvement strategies must apply to each customer group. If mobile RFID service providers target on favourable customers group with a positive attitude, they must concentrate their efforts on improving three perceived quality factors (i.e. tag recognition quality, ease of use and content quality). On the other hand, if they want to win unfavourable customers group with a negative attitude, they must not only improve four factors (i.e. tag recognition quality, connection, ease of use and content quality), but also manage adaptation cost.

The main significance of this study is that by determining factors affecting customer loyalty in mobile RFID services, we offer practical suggestions on what service improvement efforts are needed in order to increase customer loyalty and, thereby, to create the business value of this service model. However, as this study has analysed the determination of the factors which influence customer loyalty and the correlation between them through the result of online survey, there exists a limit to discuss specific factors related to mobile RFID services at this time of a pilot service, and a deeper analysis is required for the factors in the context of the service. In the future, it is demanded to evaluate users' perception of these parameters in multiple points of time as well as the empirical application of different strategies to improve selected factors to examine their influence on customers' loyalty.

Future research may also need to explore causal relationship between customer loyalty and retention because we can measure and identify the causal relationship between them when the migration of customers over to the similar services occurs after the full commercial launch of mobile RFID services. Furthermore, it is required to map out service strategies for more subdivided target customers by analysing the differences among customers' personal characteristics such as gender and age, etc. and among four customer groups (optimistic customers, impressed customers, disappointed customers, and pessimistic customers) suggested by Gerpott et al. (2001) in the future when mobile RFID services spread.

\section{References}

Aydin, S.; Ozer, G. 2005a. Customer loyalty and the effect of switching cost as a moderator variable, Marketing Intelligence \& Planning 23(1): 89-103. http://dx.doi.org/10.1108/02634500510577492

Aydin, S.; Ozer, G. 2005b. National customer satisfaction indices: an implementation in the Turkish mobile telephone market, Marketing Intelligence \& Planning 23(5): 486-504. http://dx.doi.org/10.1108/02634500510612654

Banks, J.; Pachano, M.; Thompson, L.; Hanny, D. 2007. RFID applied. John Wiley \& Sons, Inc. 509 p. http://dx.doi.org/10.1002/9780470168226

Bansal, H. S.; Taylor, S. F. 1999. The service provider switching model (SPSM): a model of consumer switching behavior in the service industry, Journal of Service Research 2(2): 200-218. http://dx.doi.org/10.1177/109467059922007

Boeck, H.; Roy, J.; Durif, F.; Grégoire, M. 2011. The effect of perceived intrusion on consumers' attitude towards using an RFID-based marketing program, Procedia Computer Science 5: 841-848. http://dx.doi.org/10.1016/j.procs.2011.07.116

Chae, M.; Kim, J.; Kim, H.; Ryu, H. 2002. Information quality for mobile internet services: a theoretical model with empirical validation, Electronic Markets 12(1): 38-46. http://dx.doi.org/10.1080/101967802753433254

Chiou, J. S. 2004. The antecedents of consumers' loyalty toward internet service providers, Information \& Management 41(6): 685-695. http://dx.doi.org/10.1016/j.im.2003.08.006 
Das, R.; Harrop, P. 2010. RFID forecasts, players and opportunities 2011-2021. IDTechEX. 278 p.

DeLone, W. H.; McLean, E. R. 2004. Measuring e-commerce success: applying the DeLone \& McLean information systems Success model, International Journal of Electronic Commerce 9(1): 31-47.

Fornell, C.; Johnson, M. D.; Anderson, E.; Cha, W. J.; Bryant, B. E. 1996. The American customer satisfaction index: nature, purpose, and findings, Journal of Marketing 60(4): 7-18. http://dx.doi.org/10.2307/1251898

Fornell, C.; Larcker, D. F. 1981. Evaluating structural equation models with unobservable variables and measurement error, Journal of Marketing Research 18(1): 39-50. http://dx.doi.org/10.2307/3151312

Gerpott, T. J.; Rams, W.; Schindler, A. 2001. Customer retention, loyalty, and satisfaction in the German mobile cellular telecommunications market, Telecommunications Policy 25(4): 249-269. http://dx.doi.org/10.1016/S0308-5961(00)00097-5

Hellier, P. K.; Geursen, G. M.; Carr, R. A.; Rickard, J. A. 2003. Customer repurchase intention: a general structural equation model, European Journal of Marketing 37(11-12): 1762-1800. http://dx.doi.org/10.1108/03090560310495456

Hiroyuki, F. 2007. Mobile RFID in Japan case studies and issues, in RFID/USN Korea 2007 International Conference, October 31-November 01, 2007, Korea.

Hong, S. J.; Tam, K. Y.; Kim, J. 2006. Mobile data service fuels the desire for uniqueness, Communications of the ACM 49(9): 89-94. http://dx.doi.org/10.1145/1151030.1151034

Hsu, H. H.; Liao, H. T. 2011. A mobile RFID-based tour system with instant microblogging, Journal of Computer and System Sciences 77(4): 720-727. http://dx.doi.org/10.1016/j.jcss.2010.02.011

Joo, Y. G.; Sohn, S. Y. 2008. Structural equation model for effective CRM of digital content industry, Expert System with Applications 34(1): 63-71. http://dx.doi.org/10.1016/j.eswa.2006.08.016

Kim, J. S.; Choi, W.; Choi, G. Y.; Pyo, C. S.; Chae, J. S. 2008. Shorted microstrip patch antenna using inductively coupled feed for UHF RFID Tag, ETRI Journal 30(4): 600-602. http://dx.doi.org/10.4218/etrij.08.0208.0074

Kim, M. J. 2007. KTF mobile RFID service, in RFID/USN KOREA 2007 International Conference, October 31-November 01, 2007, Korea.

Kim, M.; Kliger, D.; Vale, B. 2003. Estimating switching cost: the case of banking, Journal of Financial Intermediation 12(1): 25-56. http://dx.doi.org/10.1016/S1042-9573(02)00005-0

Kim, M. K.; Park, M. C.; Jeong D. H. 2004. The effects of customer satisfaction and switching barrier on customer loyalty in Korean mobile telecommunication services, Telecommunications Policy 28(2): 145-159. http://dx.doi.org/10.1016/j.telpol.2003.12.003

Klemperer, P. 1995. Competition when consumers have switching cost: an overview with applications to industrial organization, macroeconomics and international trade, Review of Economic Studies 62(4): 515-539. http://dx.doi.org/10.2307/2298075

Lai, T. L. 2004. Service quality and perceived value's impact on satisfaction, intention and usage of short message service, Information Systems Frontiers 6(4): 353-368. http://dx.doi.org/10.1023/B:ISFI.0000046377.32617.3d

Lin, H. H.; Wang, Y. S. 2006. An examination of the determinants of customer loyalty in mobile commerce contexts, Information \& Management 43(3): 271-282. http://dx.doi.org/10.1016/j.im.2005.08.001

Negash, S.; Ryan, T.; Igbaria, M. 2003. Quality and effectiveness in web-based customer support systems, Information \& Management 40(8): 757-768. http://dx.doi.org/10.1016/S0378-7206(02)00101-5

Oliver, R. L. 1997. Satisfaction: a behavioral perspective on the consumer. Boston: Irwin McGraw-Hill.

Park, Y. J.; Heo, P. S.; Rim, M. H. 2008. Measurement of a customer satisfaction index for improvement of mobile RFID services in Korea, ETRI Journal 30(5): 634-643.

http://dx.doi.org/10.4218/etrij.08.1308.0059 
Porter, M. 1998. Competitive strategy: techniques for analyzing industries and competitors. New York: Free Press. $432 \mathrm{p}$.

Rai, A.; Lang, S. S.; Welker, R. B. 2002. Assessing the validity of IS success models: an empirical test and theoretical analysis, Information Systems Research 13(1): 50-69. http://dx.doi.org/10.1287/isre.13.1.50.96

Ranaweera, C.; Prabhu, J. 2003. The influence of satisfaction, trust and switching barriers on customer retention in a continuous purchasing setting, International Journal of Service Industry Management 14(4): 374-395. http://dx.doi.org/10.1108/09564230310489231

Ramaseshan, B.; Tsao, H. Y. 2007. Moderating effects of the brand concept on the relationship between brand personality and perceived quality, Journal of Brand Management 14(6): 458-466.

http://dx.doi.org/10.1057/palgrave.bm.2550090

Sheivachman, A. 2012. RFID, mobile drive lock trends in 2012, Hotel Management 227(1): 28-29.

Shin, D. H.; Kim, W. Y. 2008. Forecasting customer switching intention in mobile service: an exploratory study of predictive factors in mobile number portability, Technological Forecasting \& Social Change 75(6): 854-874. http://dx.doi.org/10.1016/j.techfore.2007.05.001

Turel, O.; Serenko, A. 2006. Satisfaction with mobile services in Canada: an empirical investigation, Telecommunications Policy 30(5-6): 314-331. http://dx.doi.org/10.1016/j.telpol.2005.10.003

Wang, Y. S.; Liao, Y. W. 2007. The conceptualization and measurement of m-commerce user satisfaction, Computers in Human Behavior 23(1): 381-398. http://dx.doi.org/10.1016/j.chb.2004.10.017

Yang, Z.; Peterson, R. T. 2004. Customer perceived value, satisfaction, and loyalty: the role of switching cost, Psychology \& Marketing 21(10): 799-822. http://dx.doi.org/10.1002/mar.20030

Yoon, J. H. 2007. Issues \& experience of mobile RFID service trial, in RFID/USN KOREA 2007 International Conference, October 31-November 01, 2007, Korea.

Yoon, J. H. 2010. Introduction of RFID smart project, in ICT Forum KOREA 2010 Conference.

Zeithaml, V. A. 1988. Consumer perceptions of price, quality, and value: a means-end model and synthesis of evidence, Journal of Marketing 52(3): 2-22. http://dx.doi.org/10.2307/1251446

Yong-Jae PARK. She has been working as a senior researcher of KICET (Korea Institute of Ceramic Engineering and Technology) since 2012. She received a $\mathrm{PhD}$ in Business Administration from Kyungpook National University of Korea in 2006. She was a researcher in the ETRI (Electronics and Telecommunications Research Institute), Korea from 2006 to 2012. Her research interests include technology planning and industry policy in the field of information communications, RFID/USN, and ceramics.

Myung-Hwan RIM. He has been working as a principal researcher of ETRI (Electronics and Telecommunications Research Institute) after graduating from Hanyang Graduate School in 1989. He received a $\mathrm{PhD}$ in Economics from Hanyang University of Korea in 2005 and worked as a visiting scholar at Stanford University of USA in 2006. Also, he is currently the Vice President of the KITA (Korea Society of Information Technology Applications). He has carried out techno-economic analysis projects related to information technology for 25 years and published over 70 papers about economic effects and technology policy. His research interests include technology planning, R\&D management, and engineering economics in the field of information communications, RFID/USN, and digital content.

Seung-Koog LEE. He has been working as a principal researcher of ETRI (Electronics and Telecommunications Research Institute) after graduating from Graduate School of Public Administration Seoul National University in 1980. He received a $\mathrm{PhD}$ in Public Administration from Chongju University of Korea in 1988. Also, he is currently a Prof. at the Faculty of Management of Technology of the UST (University of Science and Technology) and the Vice President of the KOTIS (Korea Technology Innovation Society). He has carried out ICT policy projects for 30 years. His research interests include ICT policy, technology planning and R\&D management in the field of information communications. 